\title{
Bagassosis: An Epidemiological, Environmental, and Clinical Survey
}

\author{
C. E. D. HEARN \\ From Caroni Limited (Tate and Lyle Limited), Trinidad, West Indies
}

An epidemiological and environmental survey of 170 bagasse workers employed by a raw sugar producing company in Trinidad was carried out in order to assess the prevalence of respiratory symptoms and to determine if exposure to bagasse was associated with alterations in ventilatory capacity.

The epidemiological survey failed to reveal a significantly increased prevalence of respiratory symptoms in the more exposed group but showed that the group of Indian workers who were regularly and continuously exposed to bagasse had a significantly lower ventilatory capacity than the control group. This diminished ventilatory capacity was demonstrated despite negligible dust concentrations in the plant. However, the possibility that persistent exposure to low concentrations of bagasse may be the cause must be considered.

During a five-year period, 17 patients with bagassosis were seen, the clinical picture being similar to that described in extrinsic allergic alveolitis from other causes.

The systematic variations demonstrated in some indices of ventilatory function in different racial groups are discussed.

Bagasse is the fibrous residue of sugar-cane after the sugar has been extracted. The term was originally applied in Provence to the refuse from olive-oil mills, and its root is the Anglo-Saxon 'baeg' which referred to the olive skin as a bag. It came to apply to anything worthless.

The tough fibrous nature of bagasse and its good insulating properties have made it useful in the manufacture of hardboard, acoustic and thermal insulating materials, and certain classes of paper, and in the production of refractory brick. Recently it has been developed, on an experimental scale, into a mouldable board which can be used in the building, furniture, ship, and automotive industries. In countries producing raw sugar, bagasse finds uses as a form of bedding in stables and in deep litters for fowls, and as an inferior class of fertilizer, apart from its primary use as fuel for the sugar factory.

Inhalation of bagasse dust may give rise to the respiratory disease known as bagassosis, the clinical picture being similar to that seen in extrinsic allergic alveolitis from other causes, the classical example of which is farmer's lung.

Bagassosis was first described by Jamison and

Received for publication May 30, 1968.
Hopkins (194I) under the term 'bagasscosis' in an employee from a hard-board plant in New Orleans. Most of the reported cases have come from the southern states of the United States of America, especially Louisiana (Sodeman and Pullen, 1943, 1944; Jamison, Bryan and Day, 1944; LeMone, Scott, Moore, and Koven, 1947; Sodeman, 1949; McDaniel and Hull, 1952; Buechner, Prevatt, Thompson and Blitz, 1958). There have also been references to the disease in Italy (Cangini, 195I); India (Ganguly and $\mathrm{Pal}$, 1955; Singh, 1955; Smetana, Tandon, Viswanathan, Venkitasubramanian, Chandrasekhar, and Randhawa, 1962), and the Philippines (Dizon, Almonte, and Anselmo, 1962).

Castleden and Hamilton-Paterson (1942) reported four cases of 'bagassosis' from a factory in London and were the first to use this actual term. However, Hunter and Perry (1946), when they conducted a detailed follow-up investigation of the employees at this factory, thought that two of these cases did not show a condition which could be definitely regarded as bagassosis. This investigation revealed that, of 21 men employed on a bagasse shredding machine over a I5-month period, I I developed bagassosis. Hunter and Perry went on to describe two cases of pulmonary fibrosis which they attributed to 
exposure to bagasse dust, although these two men were less exposed than those who had developed the acute syndrome.

In 1958, Buechner and his colleagues reviewed the condition and reported three further cases, bringing the total in the world literature to 60 . The conception of bagassosis as a rare clinical entity came to an end when, out of a working population of 140 at a paper mill in Puerto Rico (Bayonet and Lavergne, I960), 69 cases occurred. The importance of bagassosis as an industrial disease was emphasized by Buechner, Aucoin, Vignes, and Weill (1964), who described the clinical features of eight cases out of an estimated total of 200 that had occurred at a board-manufacturing plant in Louisiana. A study of pulmonary function in 20 cases (Weill, Buechner, Gonzalez, Herbert, Aucoin, and Ziskind, 1966) described the restrictive defect and impairment of gas transfer, with subsequent reversal to normal on clinical improvement.

Sporadic cases are seen in Great Britain, the first recorded example since 1946 being reported by Hargreave, Pepys, and Holford-Strevens (I968).

Since Hunter and Perry (1946) carried out their retrospective investigations of the cases that occurred in a factory in London, no attempt has been made to investigate this condition specifically from the standpoint of occupational health or to determine the extent of the hazard within an industry. It was decided, therefore, to conduct an epidemiological and environmental survey of a group of 170 bagasse workers employed by a raw-sugar producing company in Trinidad in order to determine how far exposure to bagasse was associated with respiratory symptoms and with alterations in ventilatory capacity. A description of the cases encountered, with special reference to the cardinal features and the course of the disease, is also given.

\section{Operations in the Bagasse Baling Department}

The bagasse department consists of an area where bales of bagasse are stored for drying purposes, together with a small plant where they are processed for shipment overseas.

After all the juice has been extracted from the sugar-cane, the bagasse is bound into bales in a primary baling plant which is only in operation for five months of the year when the sugar crop is being reaped. The primary bales are stored in large stacks, each containing $I, 000$ tons of bagasse (Fig. I), for about 12 months to dry out.

In the process of destacking, the outer two layers of bales, which are weathered and heavily con- taminated with fungal and bacterial growth, are removed and discarded. The sound interior bales are then transported by trailer to the secondary baling plant for compression by a hydraulic ram (Fig. 2) into smaller, compact secondary bales for shipment overseas. It is here that workers are continually exposed to dust from old, and occasionally mouldy, bagasse. These men, employed in destacking operations and in the secondary baling plant, are working throughout the year operating an eight-hour shift system.

\section{Population and Methods of Study}

The Population The population studied consisted of 1 I 8 Indians and 52 Negroes, all of whom were men. The Indians in this study are the descendants of indentured immigrants who were brought into Trinidad between 1844 and 1917 to relieve the labour shortage that had occurred on the plantations after the abolition of slavery. They came from two ports of exit in India, Calcutta, and Madras. The Negroes are of West African origin, coming principally from Angola, the Congo, and the Gold Coast.

They were divided into two groups on the basis of their regularity of employment:

(a) Regular workers: These men are employed throughout the year and either work in the secondary baling plant or are concerned in the transport of bales from the stacks to the plant. They are all exposed to old bagasse.

(b) Seasonal workers: These are employed only for six months during the sugar crop and work either in the primary baling plant or out-of-doors stacking the primary bales. They are in contact with fresh bagasse only.

The Indian group consisted of $7 \mathrm{I}$ regular workers and 47 seasonal workers, while the Negro group was composed of 17 regular workers and 35 seasonal workers.

From the group of regular workers it was possible to identify a subgroup who were employed near the compressor and in the unloading area and were in regular contact with the maximum concentration of dust. This group was classified 'exposed' in contrast to the remainder who were classified 'less exposed'.

Control Groups Control groups of roo Indians and 52 Negroes were studied to establish normal values for the population under investigation. The subjects were drawn from cultivation and transport workers as a stratified random sample so as to match the age groups of the working population being studied.

The following criteria were used for acceptance as a control subject: (I) no history of cardiac or pulmonary disease ; (2) no evidence of cardiac or pulmonary disease on clinical examination; and (3) no record of having worked at any time in the bagasse department. On these criteria two subjects were rejected.

Respiratory Symptoms The presence of respiratory symptoms was assessed in the complete group of 


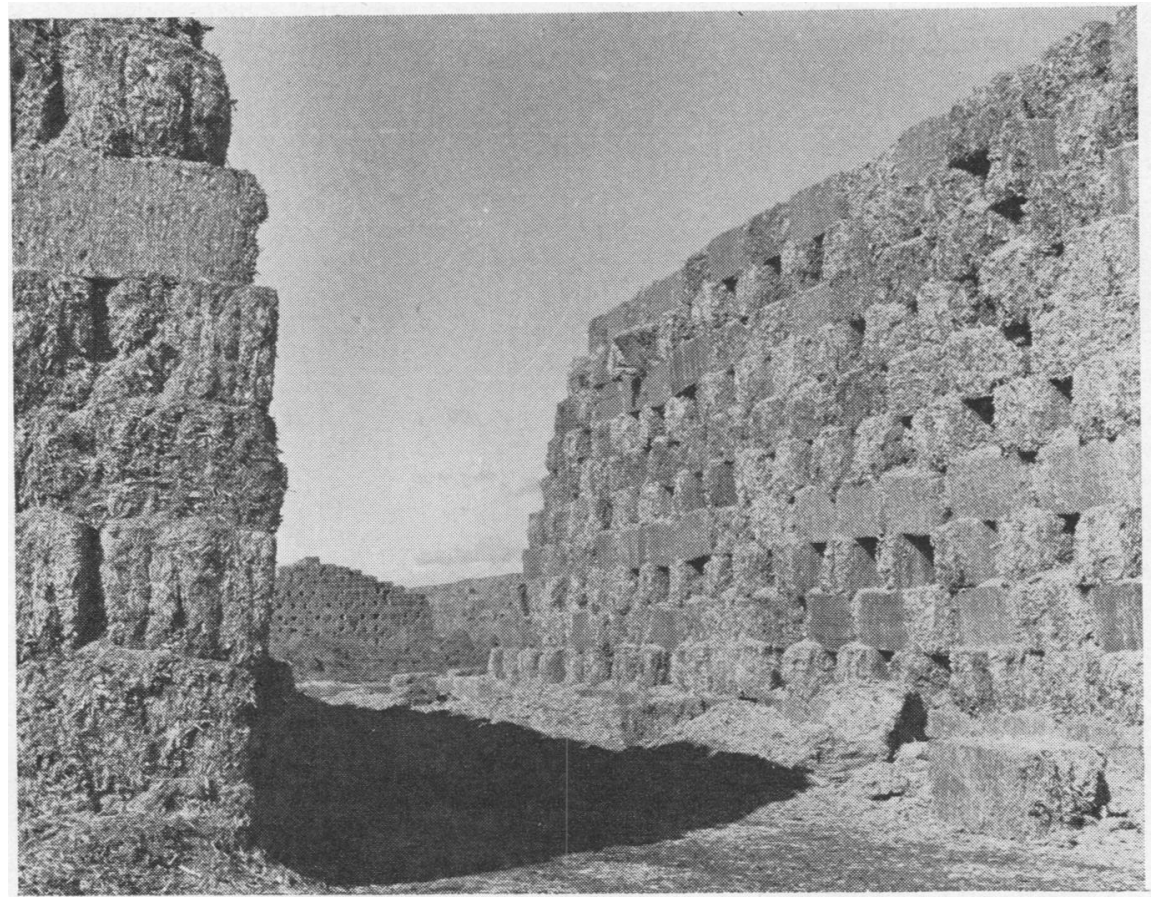

FIG. I. Bagasse stacks.

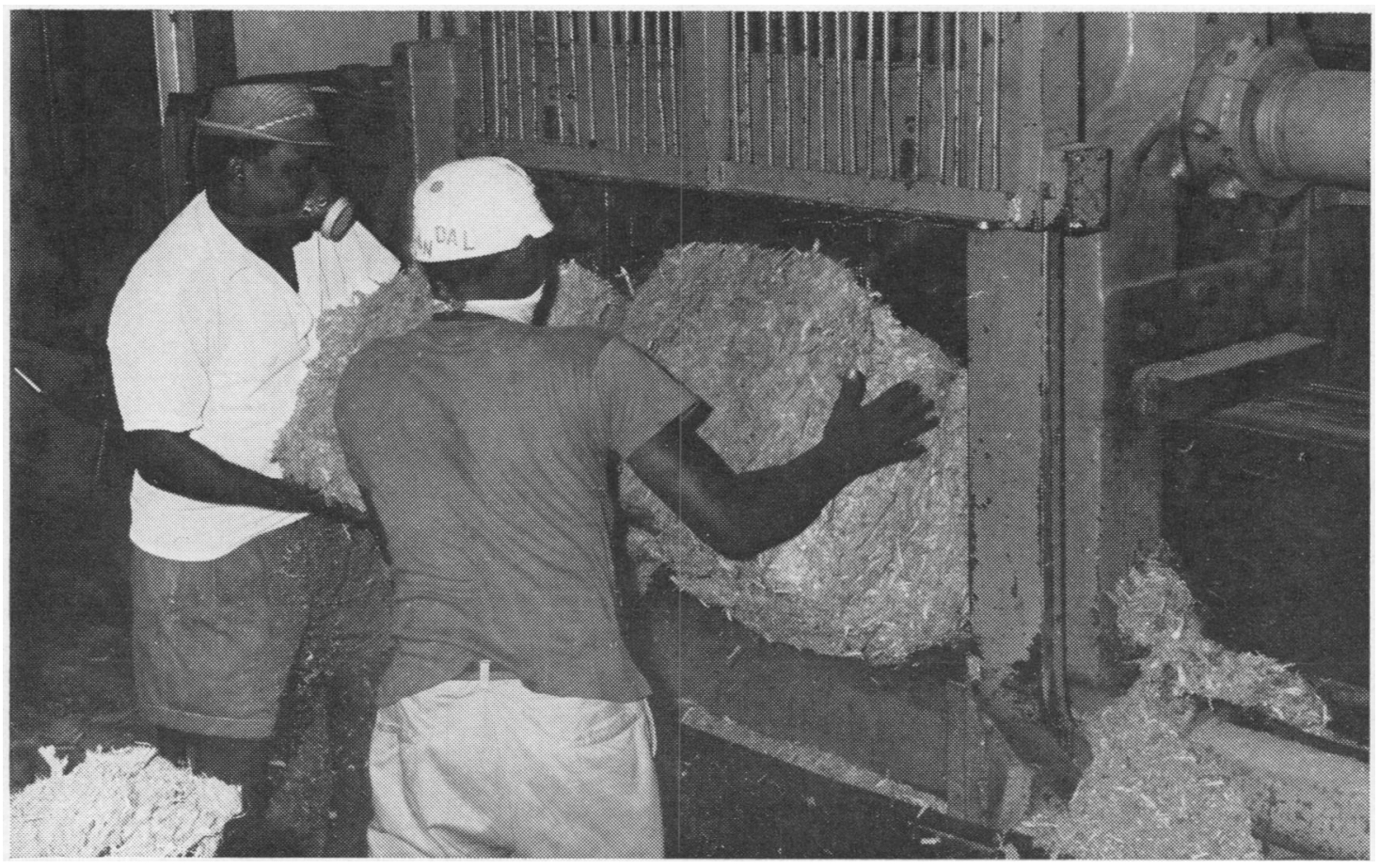

Fig. 2. Bale being loaded for compression. 
I 70 bagasse workers by using a modified questionnaire based on the Questionnaire on Respiratory Symptoms (Medical Research Council, I960a, b). All interviews were conducted personally, and where applicable the case records of an employee were also studied. These record details of all attendances at the clinic and/or of all absences from work due to illness.

The definition of chronic bronchitis used in this survey was that suggested by the Ciba symposium on terminology (Fletcher, 1959), and the term refers to subjects with "chronic or recurrent cough with expectoraation which is not attributable to conditions excluded from chronic non-specific lung disease'. Chronic or recurrent is defined as 'occurring on most days for at least three months in the year during at least two years'.

Ventilatory Capacity Tests Tests of ventilatory capacity were performed on all subjects in a room where the ambient temperature averaged $25^{\circ} \mathrm{C}$. and was not subject to undue fluctuations. The purpose of the tests was carefully explained to each subject and the technique was demonstrated by the investigator.

The height was recorded without shoes and the weight in light clothes, i.e., singlet and shorts.

Forced vital capacity (F.V.C.) estimations and forced expiratory spirograms were carried out using a dry recording spirometer, the McKesson Vitalor.
All measurements were made with the subject sitting. A nose clip was not used except in those few subjects who repeatedly attempted to take a second inspiration before they had completed their forced expiration. After two practice blows, the mean of three measurements was recorded, provided they were technically satisfactory. From the forced expiratory spirograms was calculated the forced expiratory volume in one second, as a percentage of the forced vital capacity F.E.V.1.0/F.V.C. $\%$.

All gas volumes are expressed at body temperature and pressure saturated (B.T.P.S.).

The overall means, standard deviations, coefficients of variation, and standard errors of the means for the various tests (F.V.C., F.E.V.1•0, F.E.V.1•0 $/$ F.V.C.\%) in the two racial groups are given in Tables I and II.

Dust Measurements The concentration of airborne dust particles was measured using the Hexhlet sampler described by Wright (1954). The method of sampling was based on the procedure described by Roach and Schilling (1960) but was carried out at a flow rate of 50 litres per minute during the whole of an eight-hour shift. The instrument was placed at breathing height as near a worker as possible without interfering with his work.

Measurements were made of both the total dust and the fine dust. The total dust is that which is collected

TABLE I

Overall Means, Standard Deviations, Coefficients of Variation, and Standard ERrors of Means of INDIAN GROUP

\begin{tabular}{|c|c|c|c|c|c|c|c|c|c|c|c|c|}
\hline \multirow{2}{*}{ Measurement } & \multicolumn{4}{|c|}{ Regular Workers (7I) } & \multicolumn{4}{|c|}{ Seasonal Workers (47) } & \multicolumn{4}{|c|}{ Controls (100) } \\
\hline & Mean & S.D. & C.V. $\%$ & S.E. & Mean & S.D. & C.V. $\%$ & S.E. & Mean & S.D. & C.V. \% & S.E. \\
\hline 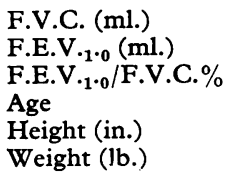 & $\begin{array}{r}3,280 \\
2,700 \\
82 \\
37 \cdot 8 \\
65 \cdot 8 \\
146\end{array}$ & $\begin{array}{r}529 \\
462 \\
6 \\
7 \cdot 8 \\
2 \cdot 4 \\
28 \cdot 5\end{array}$ & $\begin{array}{r}16 \\
17 \\
7 \\
21 \\
3 \cdot 6 \\
19\end{array}$ & $\begin{array}{r}62 \cdot 82 \\
54.83 \\
0.72 \\
0.93 \\
0.69 \\
3.38\end{array}$ & $\begin{array}{r}3,690 \\
3,100 \\
84 \\
29 \cdot 7 \\
66 \cdot 2 \\
136 \cdot 5\end{array}$ & $\begin{array}{r}599 \\
573 \\
6 \\
9 \cdot 9 \\
3 \cdot 0 \\
25 \cdot 5\end{array}$ & $\begin{array}{r}16 \\
18 \\
7 \\
30 \\
4 \cdot 5 \\
19\end{array}$ & $\begin{array}{r}87 \cdot 44 \\
83.59 \\
0.86 \\
1 \cdot 44 \\
0.44 \\
3.72\end{array}$ & $\begin{array}{r}3,650 \\
3,030 \\
83 \\
34.6 \\
65 \cdot 6 \\
135 \cdot 5\end{array}$ & $\begin{array}{r}664 \\
400 \\
3 \\
10 \cdot 3 \\
2 \cdot 3 \\
24 \cdot 6\end{array}$ & $\begin{array}{r}18 \\
13 \\
4 \\
30 \\
3.5 \\
18\end{array}$ & $\begin{array}{l}66 \cdot 4 \\
40 \cdot 0 \\
0 \cdot 34 \\
1 \cdot 03 \\
0 \cdot 23 \\
2 \cdot 46\end{array}$ \\
\hline
\end{tabular}

The figures in parentheses denote the number of subjects in the different groups.

S.D. = standard deviation

C.V. = coefficient of variation

S.E. = standard error of mean

TABLE II

Overall Mrans, Standard Deviations, Coefficients of Variation and Standard Errors of Means of NEGRO GROUP

\begin{tabular}{|c|c|c|c|c|c|c|c|c|c|c|c|c|}
\hline \multirow{2}{*}{ Measurement } & \multicolumn{4}{|c|}{ Regular Workers (17) } & \multicolumn{4}{|c|}{ Seasonal Workers (35) } & \multicolumn{4}{|c|}{ Controls (52) } \\
\hline & Mean & S.D. & C.V.\% & S.E. & Mean & S.D. & C.V.\% & S.E. & Mean & S.D. & C.V.\% & S.E. \\
\hline $\begin{array}{l}\text { F.V.C. (ml.) } \\
\text { F.E.V.1·0 (ml.) } \\
\text { F.E.V.1·0 /F.V.C. \% } \\
\text { Age } \\
\text { Height (in.) } \\
\text { Weight (lb.) }\end{array}$ & $\begin{array}{r}3,960 \\
3,320 \\
82 \\
41 \cdot 2 \\
66 \cdot 9 \\
162\end{array}$ & $\begin{array}{r}592 \\
488 \\
6 \\
8 \cdot 6 \\
3 \cdot 3 \\
30 \cdot 8\end{array}$ & $\begin{array}{r}15 \\
15 \\
7 \\
21 \\
4.9 \\
19\end{array}$ & $\begin{array}{c}143.68 \\
\text { II } 4.9 \\
1.45 \\
2.09 \\
0.80 \\
7.47\end{array}$ & $\begin{array}{r}4,130 \\
3,380 \\
82 \\
30 \cdot 8 \\
67 \cdot 7 \\
148 \cdot 5\end{array}$ & $\begin{array}{r}623 \\
540 \\
6 \\
10 \cdot 6 \\
5 \cdot 1 \\
15 \cdot 1\end{array}$ & $\begin{array}{r}15 \\
16 \\
7 \\
34 \\
7 \cdot 5 \\
10 \cdot 1\end{array}$ & $\begin{array}{r}108.46 \\
94.01 \\
1.03 \\
1 \cdot 84 \\
0.89 \\
2.63\end{array}$ & $\begin{array}{r}4,100 \\
3,420 \\
83 \\
35 \cdot 4 \\
67 \cdot 9 \\
157 \cdot 5\end{array}$ & $\begin{array}{r}618 \\
487 \\
5 \\
10 \cdot 7 \\
2 \cdot 5 \\
18 \cdot 9\end{array}$ & $\begin{array}{r}15 \\
14 \\
5 \\
30 \\
3 \cdot 7 \\
12\end{array}$ & $\begin{array}{l}85 \cdot 7 \\
67 \cdot 5 \\
0 \cdot 64 \\
1 \cdot 48 \\
0 \cdot 35 \\
2 \cdot 62\end{array}$ \\
\hline
\end{tabular}

The figures in parentheses indicate the number of subjects in the different groups. 
on the filter paper when the sampler is run without the elutriator. The fine dust is that which is collected on the filter paper when the sampler is run with the horizontal elutriator attached. The elutriator prevents the passage of particles larger than $7 \cdot 1$ microns equivalent diameter.

In the secondary baling plant, samples were collected $(a)$ in the vicinity of the compressor, $(b)$ in the covered area where the bales are unloaded from the trailers prior to compression, and $(c)$ in the storage shed while bales were being stacked.

Clinical Survey Seventeen patients with bagassosis were observed, all of whom were Indians. Eleven patients were seen before facilities were available for testing ventilatory lung function. In these, the tests were done as a follow-up study after clinical recovery had occurred, except in the case of one employee who had left the Company and could not be traced. The ventilatory capacity tests already described were carried out, and in the six patients who were studied from the onset of their illnesses, the F.E.V.1.0 and F.V.C. were measured 5 minutes after the inhalation of $1 \%$ isoprenaline sulphate as an index of reversible airways obstruction. The mixed venous $\mathrm{PcO}_{2}$ was measured using the rebreathing method of Campbell and Howell (1960, 1962). The technical difficulties in Trinidad of measuring the transfer factor unfortunately precluded its use as a field investigation.

\section{Results}

\section{Respiratory Symptoms}

Regular Workers In the group of $7 \mathrm{I}$ Indian regular workers nine gave a history of respiratory symptoms. Two of these had had an acute episode which was clinically indistinguishable from mild bagassosis. This was characterized by the insidious onset of shortness of breath and cough over a threeweek period, together with the presence of wellmarked basal crepitations. Radiological examination of the chest showed no abnormality. The symptoms and signs subsided rapidly and the men returned to work in a week. They have suffered no recurrence of symptoms and have continued to handle old bagasse for six years and four years respectively since the incident. These two subjects were seen before facilities were available for the performance of ventilatory function tests. Four workers had had an episode of acute bronchitis. One worker suffered from chronic bronchitis and one from asthma, while one complained of wheeziness associated with upper respiratory tract infections.

Two of the 17 Negro workers gave a history of respiratory symptoms, one having asthma and one being wheezy with upper respiratory tract infections.

The prevalence of respiratory symptoms in the whole group was $12 \cdot 5 \%$ (Table III).

Seasonal Workers of the 47 Indian seasonal workers, one had chronic bronchitis, one had had an episode of acute bronchitis, and two were wheezy with upper respiratory tract infections. In the Negro group of 35 workers, three were wheezy with upper respiratory tract infections. The prevalence of respiratory symptoms in the seasonal workers was $8.5 \%$ (Table III).

There is an appreciable difference in age in the two groups, the mean age of the regular Indian workers being 37.8 years and that of the regular Negro workers $4 \mathrm{I} \cdot 2$ years, compared with a mean age for the seasonal Indian workers of 29.7 years,

TABLE III

Prevalence of Respiratory Symptoms in Bagasse Workers

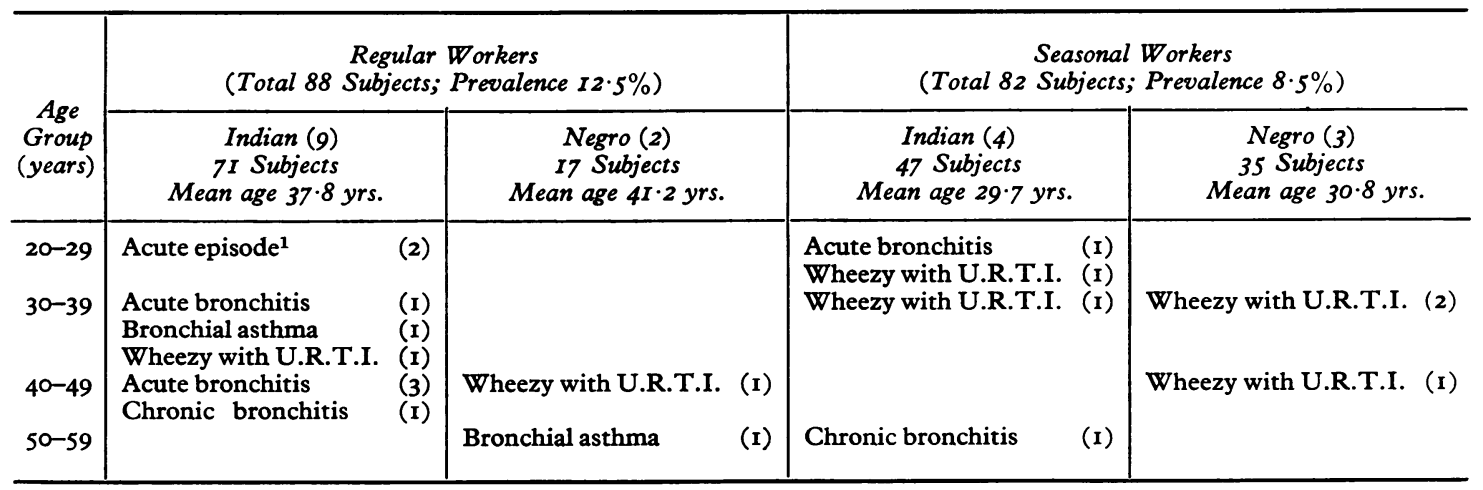

${ }^{1}$ A self-limiting illness of short duration which was indistinguishable from mild bagassosis.

U.R.T.I. = upper respiratory tract infection.

The figures in parentheses indicate the number of subjects. 
and for the seasonal Negro workers of 30.8 years. This disparity would tend to result in an increased prevalence of symptoms in the regular workers. However, the observed difference of $4 \%$ in the prevalence of respiratory symptoms in the two groups is less than the standard error of the difference between the proportions $(4 \cdot 6)$ and hence is not statistically significant.

Smoking Habits There was no major difference in the smoking habits of the different groups. These are given in Tables IV and V where the smoking habits of all workers are compared with the appropriate controls. The Negro group was in itself too small to permit any useful purpose being served by an analysis of the smoking habits of the regular and seasonal workers separately.

The smoking habits of the 71 regular Indian workers were, however, analysed separately and

TABLE IV

SMOKING HaBITS OF THE INDIAN GROUP

\begin{tabular}{|c|c|c|c|c|c|c|}
\hline $\begin{array}{c}\text { Age } \\
\text { Group }\end{array}$ & $\begin{array}{c}\text { Non- } \\
\text { smokers }\end{array}$ & $\begin{array}{c}\text { Ex- } \\
\text { smokers }\end{array}$ & Light & Medium & Heavy & Total \\
\hline \multicolumn{7}{|l|}{$\begin{array}{c}118 \text { Indian } \\
\text { Workers }\end{array}$} \\
\hline-19 & 2 & - & - & $\overline{6}$ & - & \\
\hline $20-29$ & 16 & - & 19 & 6 & 2 & 43 \\
\hline $30-39$ & 10 & I & I0 & II & - & 32 \\
\hline $40-49$ & 20 & I & 5 & 5 & - & 31 \\
\hline $50-59$ & 5 & I & I & 2 & $\mathbf{I}$ & 10 \\
\hline Percentage & 45 & 3 & 30 & 19 & 3 & - \\
\hline \multicolumn{7}{|l|}{$\begin{array}{l}7 \text { I Regular } \\
\text { Indian } \\
\text { Workers }\end{array}$} \\
\hline $20-29$ & 5 & - & 7 & 2 & - & 14 \\
\hline $30-39$ & 8 & I & 7 & 8 & - & 24 \\
\hline $40-49$ & 19 & I & 3 & 3 & I & 27 \\
\hline $50-59$ & 3 & 一 & - & 2 & I & 6 \\
\hline Percentage & 49 & 3 & 24 & 21 & 3 & - \\
\hline \multicolumn{7}{|l|}{$\begin{array}{l}\text { roo Indian } \\
\text { Controls }\end{array}$} \\
\hline-19 & 2 & - & - & - & - & 2 \\
\hline $20-29$ & 24 & - & 5 & 7 & - & 36 \\
\hline $30-39$ & 13 & - & 8 & 4 & 2 & 27 \\
\hline $40-49$ & 9 & - & 6 & 8 & 4 & 27 \\
\hline $50-59$ & 3 & - & 2 & 2 & I & 8 \\
\hline Percentage & 51 & - & $2 \mathrm{I}$ & $2 \mathrm{I}$ & 7 & - \\
\hline
\end{tabular}

Light smoker denotes a consumption of I-I4 g./day, medium smoker $15-24 \mathrm{~g}$./day, and heavy smoker 25 or more g./day.
TABLE V

SMOKING Habits OF THE Negro Group

\begin{tabular}{|c|c|c|c|c|c|c|}
\hline $\begin{array}{c}\text { Age } \\
\text { Group }\end{array}$ & $\begin{array}{c}\text { Non- } \\
\text { smokers }\end{array}$ & $\begin{array}{c}\text { Ex- } \\
\text { smokers }\end{array}$ & Light & Medium & Heavy & Total \\
\hline $\begin{array}{c}52 \text { Negro } \\
\text { Workers } \\
20-29 \\
30-39 \\
40-49 \\
50-59\end{array}$ & $\begin{array}{l}7 \\
4 \\
3 \\
2\end{array}$ & $\frac{2}{-}$ & $\begin{array}{l}6 \\
7 \\
3 \\
3\end{array}$ & $\begin{array}{l}3 \\
4 \\
3 \\
3\end{array}$ & $\bar{z}$ & $\begin{array}{r}18 \\
17 \\
9 \\
8\end{array}$ \\
\hline Percentage & $3 x$ & 4 & 36 & 25 & 4 & 一 \\
\hline $\begin{array}{c}52 \text { Negro } \\
\text { Controls } \\
20-29 \\
30-39 \\
40-49 \\
50-59\end{array}$ & $\begin{array}{r}10 \\
9 \\
2 \\
1\end{array}$ & $\frac{-}{\mathrm{r}}$ & $\begin{array}{l}7 \\
4 \\
2 \\
1\end{array}$ & $\begin{array}{l}1 \\
5 \\
4 \\
3\end{array}$ & $\begin{array}{r}- \\
\mathbf{I}\end{array}$ & $\begin{array}{r}18 \\
18 \\
9 \\
7\end{array}$ \\
\hline Percentage & 42 & 2 & 27 & 25 & 4 & - \\
\hline
\end{tabular}

Light smoker denotes a consumption of I-I $4 \mathrm{~g}$./day, medium smoker $15-24 \mathrm{~g}$./day, and heavy smoker 25 or more g./day.

compared with those of the control group of Indians (Table IV). There was no material difference in the habits of the two groups.

The smoking habits of the Indian and Negro groups in Trinidad are compared with those of Europeans (Todd, 1966) in Table VI. It can be seen that there is a much greater proportion of non-smokers in the Indian and Negro groups. In general, also, the proportion of light smokers tends to be very much higher in the two groups investigated in Trinidad than in Europeans. However, it was not possible to effect a direct

TABLE VI

SMOKING Habits OF THE INDIAN AND NEgRo Groups IN TRINIDAD COMPaRED WITH EUROPEANS

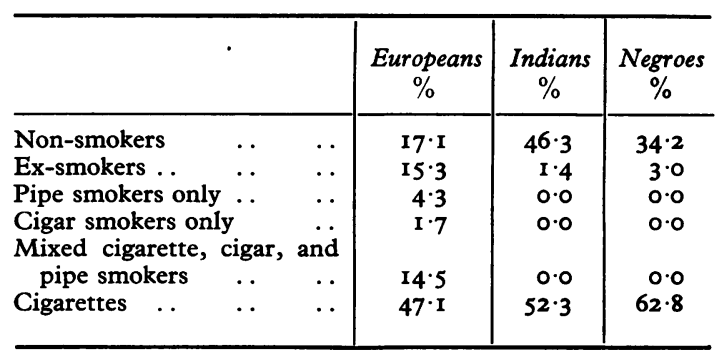

Cigarette smokers include smokers of manufactured cigarettes only, of hand-rolled cigarettes only, and of manufactured and hand-rolled cigarettes.

The figures for Europeans are taken from Statistics of Smoking in the United Kingdom (Todd, 1966). 
comparison of the smoking habits according to the amount smoked as Todd's quantitative analysis differs from the customary classification with divisions at 15 and 25 cigarettes which has been used in this analysis.

Ventilatory Capacity Tests The results were expressed as linear regressions on age and height rather than surface area, as the latter varies more with the state of nutrition at the time and bears a different relationship to weight and height for Indians than for Europeans (Banerjee and Sen, 1955).

A pooled regression was derived for the three categories of regular workers, seasonal workers, and controls in both the Indian and Negro groups. The pooled regression coefficients for these six groups are given in Table VII. The mean F.E.V.1.0 and F.V.C. for the different groups have been adjusted for age and height, and the adjusted means are given in Table VIII. Comparisons were made between the various groups and the differences tested for significance (Table IX). In order to determine whether there was any correlation between the number of years a worker was exposed and a lowered F.E.V. .1 .0 and F.V.C., a partial regression on years of exposure in relation to these two indices was included. In neither case was it statistically significant and it has been discarded.

Indian Group The adjusted mean values for both the F.E.V $\cdot 1 \cdot 0$ and the F.V.C. in the group of regular Indian bagasse workers were significantly less than in the controls $(P<0.001)$. The adjusted mean F.E.V $\cdot_{\cdot 1 \cdot 0}$ in the regular workers was 2.821 . compared with a value of $3.08 \mathrm{l}$. in the control group, while the adjusted mean F.V.C. was $3.4 \mathrm{I} 1$. in the regular workers compared with $3.71 \mathrm{I}$. in the controls.

The difference between the adjusted mean value of the F.E.V $\cdot_{1 \cdot 0}$ for the regular workers was very much less significant $(P<0.05)$. The adjusted mean F.E.V $\cdot_{1 \cdot 0}$ in the seasonal workers was 2.991 . compared with a value of $2.82 \mathrm{l}$. in the regular workers. There was no significant difference
TABLE VIII

Adjusted Mean F.E.V.1.0 AND F.V.C. IN THE Different GROUPS

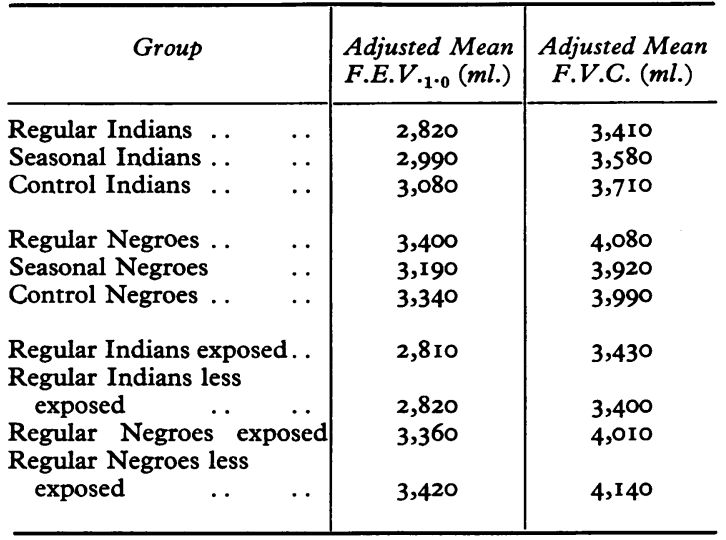

between the adjusted mean values for the F.V.C. in the two groups, the adjusted mean value for the seasonal workers being $3.58 \mathrm{l}$. compared with $3.4 \mathrm{I} 1$. for the regular workers.

The differences between the adjusted mean values of the F.E.V.$_{1 \cdot 0}$ and F.V.C. for the seasonal workers compared with the controls were not significant in either case.

The data were also examined to determine whether there was any correlation between specific occupations and lowered F.E.V.1.0 and F.V.C. From the group of 71 regular Indian bagasse workers it was possible to identify a sub-group of 3 I workers who were employed near the compressor and in the unloading area and were in regular contact with the maximum concentration of dust. A comparison of this sub-group with the remaining workers, who were employed in destacking and stacking operations and whose degree of exposure to dust was considerably less, failed to reveal significant differences.

Negro Group The differences between the adjusted mean values for the F.E.V. $\cdot_{1 \cdot 0}$ and F.V.C. in

TABLE VII

Partial Regression Coefficients (ML.) for Age (Yrs) and Height (IN.) Within the Six Groups

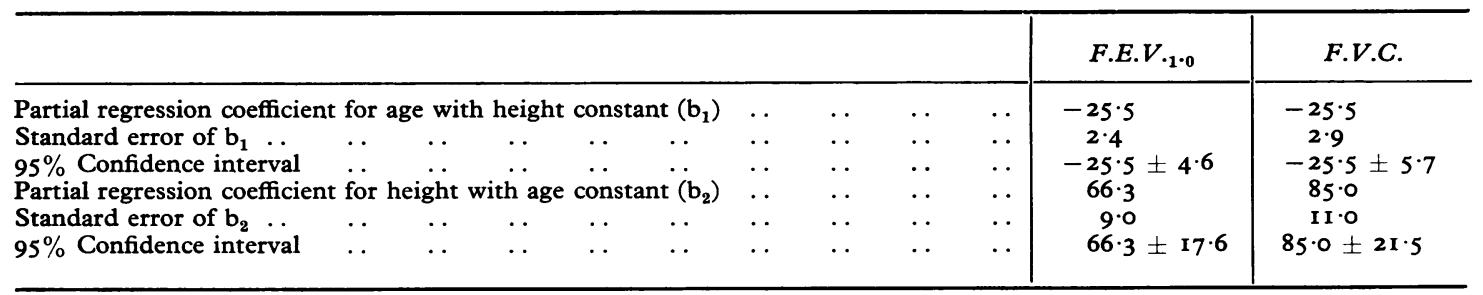


TABLE IX

Comparisons of the Differences between the Adjusted Means in the Various Groups

\begin{tabular}{|c|c|c|c|c|c|c|c|c|}
\hline Comparisons $^{1}$ & & & & & Difference $(D)$ & S.E. (D) & $t$ & $P$ \\
\hline $\begin{array}{l}\text { F.E.V.1.0 } \\
\text { Seasonal Indians } v \text {. Regular Indians } \\
\text { Control Indians } v \text {. Regular Indians } \\
\text { Control Indians } v \text {. Seasonal Indians } \\
\text { Regular Negroes } v \text {. Seasonal Negroes } \\
\text { Regular Negroes } v \text {. Control Negroes } \\
\text { Control Negroes } v \text {. Seasonal Negroes } \\
\text { Regular Negroes } v \text {. Regular Indians } \\
\text { Seasonal Negroes } v \text {. Seasonal Indians } \\
\text { Control Negroes } v \text {. Control Indians }\end{array}$ & $\begin{array}{l}\cdots \\
\cdots \\
\cdots \\
\cdots \\
\cdots \\
\cdots \\
\cdots \\
\cdots\end{array}$ & $\begin{array}{l}\cdots \\
\cdots \\
\cdots \\
\cdots \\
\cdots \\
\cdots \\
\cdots \\
\cdots\end{array}$ & $\begin{array}{l}\cdots \\
\cdots \\
\cdots \\
\cdots \\
\cdots \\
\cdots \\
\cdots \\
\cdots\end{array}$ & $\begin{array}{l}\cdots \\
\cdots \\
\cdots \\
\cdots \\
\cdots \\
\cdots \\
\cdots \\
\cdots \\
\cdots\end{array}$ & $\begin{array}{r}170 \\
260 \\
90 \\
210 \\
60 \\
150 \\
580 \\
200 \\
260\end{array}$ & $\begin{array}{r}78.6 \\
63.4 \\
72.8 \\
123.6 \\
114.4 \\
90.9 \\
110.3 \\
93.1 \\
72.4\end{array}$ & $\begin{array}{l}2 \cdot 12 \\
4 \cdot 13 \\
I \cdot 30 \\
I \cdot 69 \\
0 \cdot 56 \\
1 \cdot 59 \\
5 \cdot 30 \\
2 \cdot 24 \\
3 \cdot 56\end{array}$ & $\begin{array}{l}<0.05 \\
<0.001 \\
\text { N.S. } \\
\text { N.S. } \\
\text { N.S. } \\
\text { N.S. } \\
<0.001 \\
<0.05 \\
<0.001\end{array}$ \\
\hline $\begin{array}{l}\text { F.V.C. } \\
\text { Seasonal Indians } v \text {. Regular Indians } \\
\text { Control Indians } v \text {. Regular Indians } \\
\text { Control Indians } v \text {. Seasonal Indians } \\
\text { Regular Negroes } v \text {. Seasonal Negroes } \\
\text { Regular Negroes } v \text {. Control Negroes } \\
\text { Control Negroes } v \text {. Seasonal Negroes } \\
\text { Regular Negroes } v \text {. Regular Indians } \\
\text { Seasonal Negroes } v \text {. Seasonal Indians } \\
\text { Control Negroes } v \text {. Control Indians }\end{array}$ & $\begin{array}{l}\ldots \\
\ldots \\
\ldots \\
\cdots \\
\cdots \\
\cdots \\
\ldots \\
\cdots\end{array}$ & $\begin{array}{l}\cdots \\
\cdots \\
\ldots \\
\cdots \\
\cdots \\
\cdots \\
\ldots\end{array}$ & $\begin{array}{l}\cdots \\
\cdots \\
\cdots \\
\cdots \\
\cdots \\
\cdots \\
\cdots\end{array}$ & $\begin{array}{l}\cdots \\
\ldots \\
\ldots \\
\ldots \\
\cdots \\
\ldots \\
\ldots\end{array}$ & $\begin{array}{r}170 \\
300 \\
130 \\
160 \\
90 \\
70 \\
670 \\
340 \\
280\end{array}$ & $\begin{array}{r}96 \cdot 2 \\
77 \cdot 6 \\
89 \cdot 0 \\
151 \cdot 2 \\
139.9 \\
111 \cdot 2 \\
134 \cdot 9 \\
113.9 \\
88.6\end{array}$ & $\begin{array}{l}1 \cdot 76 \\
3 \cdot 94 \\
1 \cdot 53 \\
1 \cdot 08 \\
0 \cdot 66 \\
0.63 \\
4 \cdot 99 \\
2 \cdot 99 \\
3 \cdot 10\end{array}$ & $\begin{array}{l}\text { N.S. } \\
<0.001 \\
\text { N.S. } \\
\text { N.S. } \\
\text { N.S. } \\
\text { N.S. } \\
<0.001 \\
<0.01 \\
<0.01\end{array}$ \\
\hline
\end{tabular}

${ }^{1}$ In each instance the group with the larger mean is the first mentioned.

N.S. = not significant $-\mathrm{P}>0.05$

the three categories of regular workers, seasonal workers, and controls in the Negro group were not significant in any instance.

Variations between Racial Groups The adjusted mean values for the F.E.V.1.0 and F.V.C. for the different groups of Negroes compared with the corresponding Indian groups all showed significant differences, the Negro having a larger ventilatory capacity than the Indian. In the control groups, the adjusted mean F.E.V.1.0 3.34 1. compared with 3.081 . in the Indians ( $\mathrm{P}<0.00 \mathrm{I}$ ), while the adjusted mean F.V.C. was 3.99 l. in the Negroes compared with 3.71 1 . in the Indians $(\mathrm{P}<0.0 \mathrm{I})$. In the seasonal group of workers, the adjusted mean F.E.V.1.0 in the Negroes was 3.19 1. compared with 2.99 1. in the Indians $(P<0.05)$, while the adjusted mean F.V.C. was 3.921 . in the Negroes compared with 3.581 . in the Indians $(\mathrm{P}<0.0 \mathrm{I})$. In the regular group of workers, the adjusted mean F.E.V.1.0 in the Negroes was 3.401 . compared with 2.821 . in the Indians $(\mathbf{P}<0.001$ ), while the adjusted mean F.V.C. was 4.081 . in the Negroes compared with 3.411 . in the Indians $(\mathrm{P}<0.00 \mathrm{r})$.

Dust Measurements One hundred samples were collected and the dust concentrations are shown in Table X. They were negligible in all areas. The highest concentrations were in the unloading area where the total dust ranged from 0.09 to $\mathrm{I} .42 \mathrm{mg} . / \mathrm{m}^{3}$ with a mean of $0.71 \mathrm{mg} . / \mathrm{m}^{3}$; and the fine dust ranged from 0.02 to $0.31 \mathrm{mg} . / \mathrm{m}^{3}$ with a mean of $0.13 \mathrm{mg} . / \mathrm{m}^{3}$

Clinical Features During a five-year period, 17 patients with bagassosis were seen, three of whom were not workers in the bagasse baling plant but grooms, who were exposed to bagasse used as bedding in stables. The 14 cases in the bagasse baling plant all occurred in workers employed in the secondary baling plant, either on the compressor, in the unloading area or as stackers. None was seen in workers employed in the primary baling plant who were only exposed to fresh bagasse.

The onset was insidious in 15 and acute in two. An acute onset, which was associated with pyrexia, tended to occur after exposure to an unusually high dust concentration. The period of exposure before the development of symptoms varied from four months to 12 years.

The presenting symptom in all patients was increasingly severe and profound shortness of breath. This was accompanied by a cough which was usually dry and irritant but in six cases was productive of scanty mucoid sputum. Haemoptysis, 
TABLE $X$

Dust Concentrations in the Bagasse Baling Plant

\begin{tabular}{|c|c|c|c|c|c|c|}
\hline \multirow{3}{*}{ Site } & & \multirow{3}{*}{$\begin{array}{c}\text { No. of } \\
\text { Samples }\end{array}$} & \multicolumn{4}{|c|}{ Dust Concentration (mg./m. ${ }^{3}$ ) } \\
\hline & & & \multicolumn{2}{|c|}{ Fine } & \multicolumn{2}{|c|}{ Total } \\
\hline & & & Mean & Range & Mean & Range \\
\hline Primary baling plant & . & 15 & 0.06 & $0.04-0.08$ & 0.26 & $0.08-0.71$ \\
\hline $\begin{array}{l}\text { Secondary baling plant } \\
\text { In vicinity of compressor } \\
\text { In unloading area } \\
\text { In the storage shed }\end{array}$ & $\begin{array}{l}\cdots \\
\cdots \\
\cdots\end{array}$ & $\begin{array}{r}15 \\
15 \\
5\end{array}$ & $\begin{array}{l}0.09 \\
0.13 \\
0.03\end{array}$ & $\begin{array}{l}0.02-0.16 \\
0.02-0.31 \\
0.02-0.05\end{array}$ & $\begin{array}{l}0.42 \\
0.71 \\
0.08\end{array}$ & $\begin{array}{l}0.08-1 \cdot 63 \\
0.09-1 \cdot 42 \\
0.06-0.13\end{array}$ \\
\hline
\end{tabular}

pleural pain, and sweats were not a feature, but loss of weight, of ro lb. and $14 \mathrm{lb}$., occurred in two patients.

A constant feature on clinical examination was the presence of crepitations, which were predominantly basal, but in the more severe cases were generalized. There was no wheezing, and signs of consolidation were absent. Neither cyanosis nor clubbing was seen.

The white blood count was within normal limits, but the erythrocyte sedimentation rate was slightly to moderately raised in all cases, the average value being $23 \mathrm{~mm}$. in the first hour (range 10-36). The Mantoux test was negative in I I cases. Histoplasmin reactions were negative in 16 cases. In the remaining case the test was not carried out as the patient had left the Company and could not be traced. In the six cases in which sputum was produced, no tubercle bacilli could be demonstrated. The mixed venous $\mathrm{PCO}_{2}$ was within normal limits in all cases.

Radiological examination of the chest showed fine micro-nodular shadowing in 15 cases, which was either confined to, or, if more diffuse, was predominant at, the bases. The hilar glands were not entarged. In all cases there was complete regression of the radiological changes with a return to normality in an average period of eight weeks (range 4-2I weeks). At an early stage in four cases there were no radiological changes, although clinical signs were evident. In two cases the radiological appearances were normal throughout.

In the six patients in whom ventilatory function tests were performed from the onset of their illness there was a moderate reduction in the F.E.V.1.0 and F.V.C. The F.E.V.1.0 as a percentage of the F.V.C. was in the normal range, and in no case was it below 70\%. There was no evidence of reversible airways obstruction as shown by an absence of improvement in the F.E.V.1.0 and F.V.C. after inhalation of isoprenaline. The ventilatory function tests returned to normal in all cases over a period of two to four months (Table XI). One of these patients (Case II) had a normal chest radiograph throughout his illness. In the ro patients in whom ventilatory function tests were carried out as a follow-up study after clinical recovery had occurred, no significant departure from normal was found. With the avoidance of further exposure, spontaneous recovery occurred in all patients in an average period of six weeks (range 3- I3 weeks).

Two cases experienced a mild episode, with typical symptoms and signs but no radiological changes, which subsided rapidly. Each returned to normal work and despite further exposure remained symptom-free for six months before developing a more severe and prolonged recurrence. These two cases may be compared with the two Indian regular workers who have had no recurrence over a six-year and four-year period since returning to their usual employment.

Representative case histories are presented below, illustrating an insidious onset (Case 7) and an acute onset (Case 13).

Case 7 An Indian aged 46 had been employed for the previous 12 years unloading bales for compressing. He presented with a two months' history of the insidious onset of shortness of breath associated with cough and scanty mucoid sputum. The breathlessness forced him to stop even when walking slowly. There was no haemoptysis and no loss of weight. There were no relevant features in the past history. He was a nonsmoker. On examination he was apyrexial, and there was no cyanosis or clubbing. He had a frequent cough. There was diminished air entry and profuse crepitations at the bases of both lungs. The other systems were normal.

The chest radiograph showed a fine mottling of both lungs more marked at the bases and on the left side (Figs 3 and 4). Sputum culture was negative for acidfast bacilli. The tuberculin skin test was negative to 
TABLE XI

Ventilatory Function Test Values in the Patients with Bagassosis followed up throughout their Illness

\begin{tabular}{|c|c|c|c|c|c|}
\hline Patient No. & Age & Date & F.E.V. $\cdot_{\cdot 1 \cdot 0}(l)$. & F.V.C. (l.) & M.V.V. (l./min.) \\
\hline I I & 26 & $\begin{array}{l}\text { 15. } 2.63 \\
\text { 15. } 3.63 \\
\text { I2. } 4.63\end{array}$ & $\begin{array}{l}2 \cdot 20 \\
2 \cdot 47 \\
2 \cdot 79\end{array}$ & $\begin{array}{l}2 \cdot 68 \\
2 \cdot 90 \\
3 \cdot 38\end{array}$ & $\begin{array}{r}74 \\
98 \\
117\end{array}$ \\
\hline 12 & 24 & $\begin{array}{l}\text { 15. } 2.63 \\
\text { 15. } 3.63 \\
\text { 12. } 4.63\end{array}$ & $\begin{array}{l}2.85 \\
3.22 \\
2.90\end{array}$ & $\begin{array}{l}3.11 \\
3.65 \\
3.44\end{array}$ & $\begin{array}{r}96 \\
110 \\
154\end{array}$ \\
\hline 13 & 36 & $\begin{array}{r}\text { I5. } 2.63 \\
8.3 .63 \\
\text { I5. } 3.63 \\
\text { I2. } 4.63 \\
7.5 .63\end{array}$ & $\begin{array}{l}1 \cdot 66 \\
1 \cdot 82 \\
2 \cdot 09 \\
2 \cdot 25 \\
2 \cdot 42\end{array}$ & $\begin{array}{l}1 \cdot 99 \\
2 \cdot 31 \\
2 \cdot 63 \\
2 \cdot 79 \\
3 \cdot 01\end{array}$ & $\begin{array}{r}62 \\
68 \\
80 \\
86 \\
107\end{array}$ \\
\hline 14 & 26 & $\begin{array}{r}\text { 16. } 9.63 \\
28.9 .63 \\
5.10 .63 \\
23.1 .64\end{array}$ & $\begin{array}{l}2 \cdot 20 \\
2 \cdot 58 \\
3 \cdot 01 \\
3 \cdot 11\end{array}$ & $\begin{array}{l}2 \cdot 25 \\
2 \cdot 79 \\
3 \cdot 38 \\
3 \cdot 65\end{array}$ & $\begin{array}{r}64 \\
75 \\
128 \\
121\end{array}$ \\
\hline 15 & 56 & $\begin{array}{r}\text { 4. } 2.64 \\
\text { 29. } 2.64 \\
\text { I4. } 5.64\end{array}$ & $\begin{array}{l}x \cdot 56 \\
1 \cdot 77 \\
2 \cdot 04\end{array}$ & $\begin{array}{l}2 \cdot 20 \\
2 \cdot 52 \\
2 \cdot 79\end{array}$ & $\begin{array}{l}52 \\
60 \\
71\end{array}$ \\
\hline 16 & 46 & $\begin{array}{l}\text { I8. } 4.63 \\
\text { I6. } 5.63 \\
\text { I4. } 6.63\end{array}$ & $\begin{array}{l}1 \cdot 93 \\
2 \cdot 47 \\
3 \cdot 12\end{array}$ & $\begin{array}{l}2 \cdot 25 \\
2 \cdot 95 \\
3 \cdot 49\end{array}$ & $\begin{array}{r}72 \\
84 \\
108\end{array}$ \\
\hline
\end{tabular}

I00 T.U. The histoplasmin skin test was negative to I : roo. E.S.R. (Westergren) was $14 \mathrm{~mm}$./Ist hr. (corrected). W.B.C. was $9,800 / \mathrm{cu}$. mm. (polymorphs 5,488 (56\%), eosinophils $392(4 \%)$, basophils nil, lymphocytes $3,528(36 \%)$, monocytes $392(4 \%))$. Precipitins against Micropolyspora faeni were present in the serum, and a reaction was also obtained against Thermoactinomyces vulgaris using higher antigen concentrations. An inhalation test with an extract of Thermoactinomyces vulgaris produced a response typical of a precipitinmediated type of hypersensitivity, but inhalations with extracts of Micropolyspora faeni failed to produce any reactions (Hearn and Holford-Strevens, 1968).

He was taken off work and treated symptomatically. After two weeks he had improved sufficiently to be able to walk slowly without breathlessness but there was no change in the physical signs. In a further two weeks he was breathless on mild exertion only and his cough was less. Crepitations were still audible at both bases although less in amount. The chest radiograph showed considerable clearing. A fortnight later there was no abnormal breathlessness and his cough had ceased, although persistent crepitations were still audible at both bases on deep inspiration. In a further week there were no abnormal auscultatory signs. A follow-up radiograph was carried out three weeks later and showed complete clearing. Follow-up ventilatory function studies carried out two years after the illness showed no significant departure from normal.
Case 13 An Indian aged 36 was employed as a groom. Bagasse was being used as bedding in one of the stables and the bales were being broken up in the confined and ill-ventilated space of an empty stall. No protective measures were being taken. He had been exposed to this hazard for four months before developing symptoms.

He presented with an acute febrile episode associated with malaise and dry cough and a temperature of $100^{\circ}{ }^{\circ} \mathrm{F}$. Examination of the chest showed harsh vesicular breathing and rhonchi. His occupational exposure was not realized at this stage, and he was considered to be suffering from acute bronchitis and was treated symptomatically. He made an uneventful recovery and returned to work in Io days. He re-attended a month later with a history that he had developed shortness of breath and cough shortly after returning to work and that this had got progressively worse. He was now breathless even at rest. There was scanty mucoid sputum. There had been no haemoptysis or loss of weight. He was a non-smoker. On examination he had a temperature of $100^{\circ}{ }^{\circ} \mathrm{F}$. There was no cyanosis or clubbing. He had a frequent cough and his breathing was very shallow as paroxysms of coughing were easily provoked. There was diminished air entry at the bases and profuse crepitations all over both lung fields. The other systems were normal.

The chest radiograph showed a fine diffuse mottling with some nodular shadows in both middle and lower 


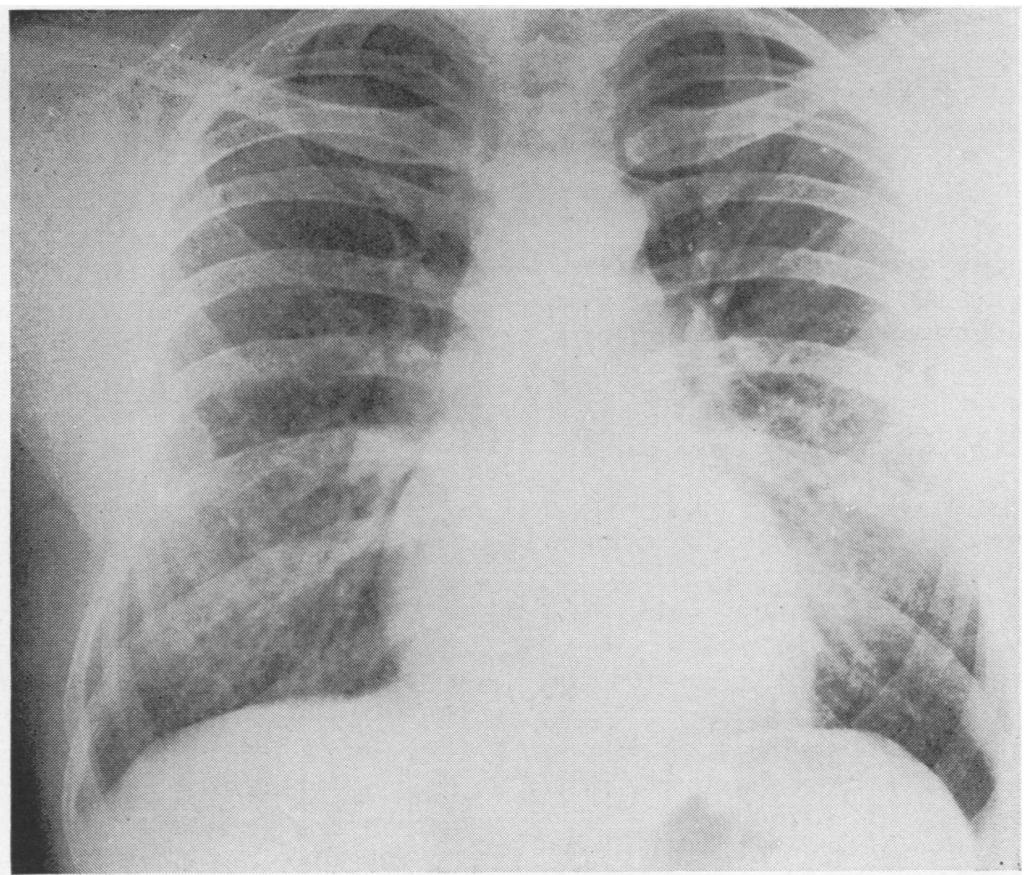

FIG. 3. Case 7. Chest film showing fine mottling of both lungs, more marked at the bases. (Below) Enlargement of lower portion of right lung, showing the fine nodular appearance of the shadowing.

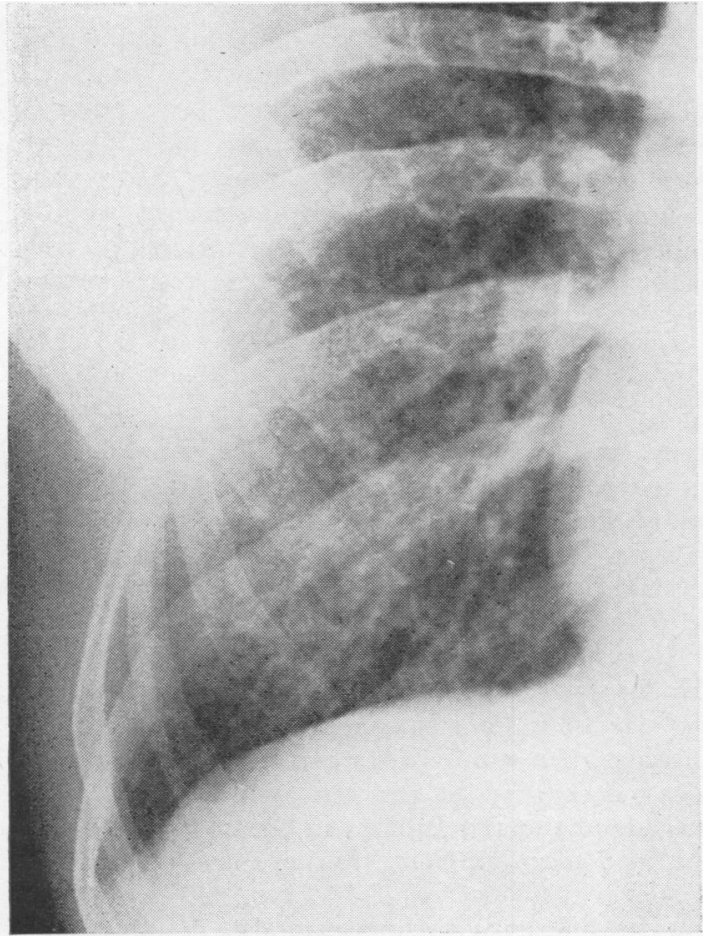

zones, rather more marked on the right. Sputum culture was negative for acid-fast bacilli. The tuberculin skin test was positive to roo T.U. The histoplasmin skin test was negative to $\mathrm{I}:$ IOO. E.S.R. (Westergren) was $36 \mathrm{~mm}$./1st hr (corrected). W.B.C. was 7,200 per cu. mm. (polymorphs 3,960 (55\%), eosinophils $216(3 \%)$, basophils nil, lymphocytes $2,880(40 \%)$, monocytes I $44(2 \%)$. The mixed venous $\mathrm{Pco}_{2}$ was $49 \mathrm{~mm}$. Hg. Precipitins against bagasse extracts were present in the serum. An inhalation test with an extract of Thermoactinomyces vulgaris produced a response typical of a precipitin-mediated type of hypersensitivity reaction (Hearn and Holford-Strevens, 1968).

Ventilatory function tests (Table XI) showed a moderate reduction in the forced vital capacity and in the maximum voluntary ventilation. There was an absence of airways obstruction as evidenced by the normal value for the F.E.V. $\cdot_{1 \cdot 0} /$ F.V.C. $\%$ and the lack of demonstrable improvement in this index after the inhalation of isoprenaline.

He was taken off work and further exposure was prevented. After four days he was still pyrexial $\left(99^{\cdot{ }^{\circ}} \mathrm{F}\right.$.) but the dyspnoea was much less. Crepitations were now confined to both lower lobes. He showed a gradual improvement over the following two weeks and by then the pyrexia had subsided and he was able to walk slowly without breathlessness. Numerous crepitations were still audible at both lung bases. The chest radiograph a month after he presented showed some clearing, and in a further four weeks he was symptom-free and 
there were no abnormal auscultatory signs. The radiograph had also returned to normal. Follow-up ventilatory function studies (Table XI) showed a steady improvement to within normal limits.

\section{Discussion}

The epidemiological survey of the 170 bagasse workers failed to reveal a significantly increased prevalence of respiratory symptoms in the more exposed group, although the difference in age between the groups tended to favour an increased prevalence of symptoms in the older regular workers.

The validity of answers given to a questionnaire such as this must be critically assessed in relation to the population to which it is applied. It could perhaps be queried whether a group of unskilled workers in a developing country with a serious unemployment problem might be liable to deny the presence of symptoms. The average employee has a paradoxical attitude towards illness. Although he tends to make much of minor departures from health and to magnify the inconsequential, he will, on the other hand, show an astounding degree of lack of awareness and lack of appreciation of many obvious and ominous symptoms. Such factors do not render the assessment of a questionnaire any easier, but in the present investigation would probably tend to give a bias in the direction of the presence of symptoms in a group of workers who are aware of the possibility of an environmental hazard.

In applying tests of ventilatory function in a field survey such as this, special attention must be given to the psychological characteristics of the population and the possible effect that motivation may have on the results. Paul, Fletcher, and Addison (1960), in a comparative study between Europeans and Africans in the mining industry in what was then known as Northern Rhodesia, drew attention to the failure of Africans to make an adequate inspiratory effort for the taking of chest radiographs. In fact, they had to give their patients specific preliminary instruction before they could get satisfactory films which were otherwise taken in the mid-expiratory or expiratory phase. This characteristic may be due to a lack of appreciation of the necessity for making the effort, or to a natural reluctance occasioned by the tropical ambience, or a combination of both.

As many tests of ventilatory function depend on an initial full inspiratory effort, this characteristic of the African is important. A similar tendency was noted in the population under study and was a feature of both racial groups, although more marked in the Indian. It was not, however, a greater problem in the workers than in the controls. It merely underlines the importance of careful and detailed explanation to the individual subject, and of the need to win the co-operation and confidence of someone who may be suspicious of the motives of the investigator. However, the problem of ensuring an adequate effort by all subjects can be overcome if a spirit of competition is fostered, encouraged by a reward for the highest value.

It was noticed early in the investigation, during 1962, that the values for the F.E.V $\cdot_{1 \cdot 0}$ and F.V.C. in both the Indians and Negroes were lower than those that would be expected for Europeans of the same age, height, and weight. These systematic variations in the normal values of some indices of lung function shown by people of different racial groups have only recently attracted attention. Cotes and Malhotra (1965), in comparing in the same laboratory 17 Indian military personnel with 30 Welsh factory workers, have shown that the F.E.V..$_{1.0}$ and F.V.C. in Indians are smaller than in Europeans, while similar variations have been demonstrated in Polynesians (Glass, 1962). Gilson, Stott, Hopwood, Roach, McKerrow, and Schilling (1962) found the I.M.B.C. to be lower in East Africans than would be expected for Europeans of the same age, the smaller size of the African accounting for only part of this difference.

Pulmonary function studies involving estimations of vital capacity, forced expiratory volume, and maximum breathing capacity have been reported from India (Singh and Prabhakaran, 1957; Gogate, Gaula, and Patil, 196I; Khandare and Sen, 1962). Such studies have used medical students and the staff of medical colleges as subjects, and, owing to the selected population and more restricted age groups, do not permit of direct comparison with the population under study.

For comparative purposes the predicted values for the F.V.C. and F.E.V.1.0 for an Indian in the control group aged 23 years, height 67 in., were compared with the mean values obtained by Cotes and Malhotra (1965) in 17 Indian military personnel, their data having been standardized to the same age and height. It can be seen from Table XII that the values are closely similar.

Cotes (1965) has pointed out that the lowered ventilatory capacity, when standardized for age and size, of Indians as compared with Europeans is related to the subdivisions of the lung volume and does not extend to the airway resistance. The analysis of the roo Indians in the control group in Trinidad supports Cotes' findings in relation to the smaller vital capacity of Indians, and also shows that the difference does not extend to the proportion 
TABLE XII

Predicted Values for an Indian in the Control GROUP, AGED 23 YEARS, HEIGHT 67 INCHES, COMPARED with Mean Values obtained by Cotes and

Malmotra (1965) In INDian Military Personnel. STANDARDized to SAME Age aNd Height

\begin{tabular}{|c|c|c|c|}
\hline Measurement & Units & $\begin{array}{l}\text { Indian } \\
\text { Control } \\
\text { Group, } \\
\text { Trinidad }\end{array}$ & $\begin{array}{c}\text { Indian } \\
\text { Military } \\
\text { Personnel } \\
\text { (Cotes and } \\
\text { Malhotra, } \\
\text { I965) }\end{array}$ \\
\hline $\begin{array}{lll}\text { F.V.C. } . . & \ldots & \ldots \\
\text { F.E.V.1.0 } & \ldots & \ldots \\
\text { F.E.V.1.0 } & \text { F.V.C. } \times & \text { 100 }\end{array}$ & $\begin{array}{l}\text { litres } \\
\text { B.T.P.S. } \\
\text { litres } \\
\text { B.T.P.S. } \\
\%\end{array}$ & $\begin{array}{c}4 \cdot 10 \\
\\
3 \cdot 42 \\
83 \cdot 4\end{array}$ & $\begin{array}{c}4 \cdot 18 \\
\\
3 \cdot 49 \\
83 \cdot 4\end{array}$ \\
\hline
\end{tabular}

of the forced vital capacity which can be expired in one second. It is of considerable interest that the figures for the Indians in the control group in Trinidad should have been so closely similar to the values obtained by Cotes and Malhotra (1965). The average Indian sugar worker tends to be in poor physical condition and it might have been expected that his ventilatory capacity would have contrasted with that of military personnel. That this is not so underlines the relative importance of inherited racial characteristics rather than acquired physical attributes in determining the ventilatory capacity of a group.

The predicted values for the F.V.C. and F.E.V.1.0 for a Negro in the control group were then compared with the mean values obtained by Cotes and Malhotra (1965) for Europeans, the same standardization obtaining with regard to age and height (Table XIII).

It can be seen that the Trinidadian Negro has an appreciably smaller vital capacity than the

TABLE XIII

Predicted Values for a Negro in the Control GROUP, AGED 23 YEARS, HEIGHT 67 INCHES, COMPARED With Mean Values obtained by Cotes aNd Malhotra

(1965) In EURopeans, STANDARDIZEd TO SAME AgE AND HEIGHT

\begin{tabular}{|c|c|c|c|}
\hline Measurement & Units & $\begin{array}{c}\text { Negro } \\
\text { Control } \\
\text { Group, } \\
\text { Trinidad }\end{array}$ & $\begin{array}{c}\text { Europeans } \\
\text { (Cotes and } \\
\text { Malhotra, } \\
\text { 1965) }\end{array}$ \\
\hline 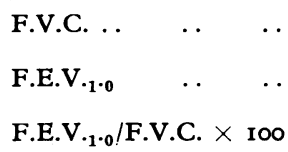 & $\begin{array}{l}\text { litres } \\
\text { B.T.P.S. } \\
\text { litres } \\
\text { B.T.P.S. } \\
\text { \% }\end{array}$ & $\begin{array}{c}3 \cdot 68 \\
84 \cdot 8\end{array}$ & $\begin{array}{r}4 \cdot 93 \\
4 \cdot 06 \\
82 \cdot 5\end{array}$ \\
\hline
\end{tabular}

European, and again that this difference does not extend to the proportion of the forced vital capacity which can be expired in one second. The Trinidadian Negro is of West African origin, coming principally from Angola, the Congo, and the Gold Coast. Although some variations have been noted in East Africans (Paul et al., 1960; Gilson et al., 1962), there is no information on the value encountered in the West African.

When the adjusted mean values for the F.E.V $\cdot_{1 \cdot 0}$ and F.V.C. for the different groups of Negroes were compared with the corresponding Indian groups (Table IX) it was shown that the ventilatory capacity of the Negro was significantly higher.

The analysis of the ventilatory function tests carried out in the bagasse workers showed that the mean values for the F.E.V. $\cdot_{1 \cdot 0}$ and F.V.C. were significantly lower in the $7 \mathrm{I}$ regular Indian workers than in the control Indian group $(P<0.001)$.

In attempting to assess the importance of the difference between the mean values for the F.E.V . 1.0 and F.V.C. shown by the regular Indian workers as compared with the control group, it has been established that there was no material difference in the smoking habits of the two groups that could be held accountable. All the tests were carried out between 8.00 a.m. and 10.30 a.m., so that the circadian variation in ventilatory capacity described by Walford, Lammers, Schilling, Genderen, and Veen (1966) caninot be a factor.

The control group was selected to the extent that two subjects from the sample were rejected as they had respiratory disease. In the group of regular Indian workers there were nine individuals with respiratory symptoms. The actual F.V.C. of each of these has been compared with the predicted F.V.C. as calculated from the data.

It will be seen from Table XIV that only three individuals (Subjects 15, 33, and 96) have values markedly below normal. This constitutes such a small group that it could not have influenced the regression to any appreciable extent and cannot therefore be the explanation of the difference in the mean values that has been demonstrated.

The possibility that persistent exposure to low concentrations of bagasse may be the cause of the diminution in ventilatory capacity shown by the group of Indian regular workers must be considered. It is of interest that this diminished ventilatory capacity was demonstrated despite dust concentrations in the plant which were negligible. Although absolute concentrations of dust are admittedly not the important factor, but rather the degree of fungal contamination and antigenicity, they do give some indication of the degree of environmental contamination. 
TABLE XIV

Actual F.V.C. compared with Predicted F.V.C. IN NINE SUBJECTS WITH RESPIRATORY SYMPTOMS IN REGULAR GROUP OF INDIAN WORKERS

\begin{tabular}{|c|c|c|c|c|}
\hline Subject & Diagnosis & $\begin{array}{l}\text { F.V.C. } \\
\text { Actual } \\
\text { (litres) }\end{array}$ & $\begin{array}{c}\text { F.V.C. } \\
\text { Predicted } \\
\text { (litres) }\end{array}$ & $\begin{array}{c}\% \\
\text { Predicted }\end{array}$ \\
\hline $\begin{array}{r}7 \\
15 \\
33 \\
35 \\
38 \\
74 \\
96 \\
105 \\
\\
123\end{array}$ & $\begin{array}{l}\text { Acute episode }{ }^{1} \\
\text { Acute bronchitis } \\
\text { Acute bronchitis } \\
\text { Acute bronchitis } \\
\text { Acute episode }^{1} \\
\text { Bronchial asthma } \\
\text { Chronic } \\
\text { bronchitis } \\
\text { Wheezy with } \\
\text { U.R.T.I. } \\
\text { Acute bronchitis }\end{array}$ & $\begin{array}{l}4 \cdot 04 \\
2 \cdot 66 \\
2 \cdot 23 \\
3 \cdot 29 \\
4 \cdot 25 \\
4 \cdot 19 \\
2 \cdot 43 \\
3 \cdot 12 \\
2 \cdot 79\end{array}$ & $\begin{array}{l}4 \cdot I \mathrm{I} \\
3 \cdot 83 \\
3 \cdot 44 \\
3 \cdot 98 \\
3 \cdot 91 \\
3 \cdot 57 \\
\\
3 \cdot 49 \\
\\
3 \cdot 69 \\
3 \cdot 32\end{array}$ & $\begin{array}{r}98 \\
69 \\
65 \\
83 \\
109 \\
117 \\
\\
70 \\
\\
\\
84 \\
84\end{array}$ \\
\hline
\end{tabular}

${ }^{1} A$ self-limiting illness of short duration indistinguishable from mild bagassosis.

A comparison of the sub-group of 31 workers employed in the vicinity of the compressor and in the unloading area with the remainder of the group, who were apparently less exposed, failed to reveal a significant difference in ventilatory capacity. The differentiation into 'exposed' and 'less exposed' groups is, however, not absolute as some irregular interchange occurs when workers have to act for short periods as a relief in the other group at times of illness or during holidays. Further, the apparently 'less exposed' group were employed in stacking and destacking operations outside, a considerable distance away from a source of compressed air, where it was not possible to carry out dust measurements. It may be that their degree of exposure, although intermittent and variable, is greater than it appears to be.

The sporadic incidence of bagassosis in the working population, the individual susceptibility shown by the exposed employees, and the occurrence of the disease only in those exposed to old, as opposed to fresh, bagasse are characteristic of pulmonary hypersensitivity disease due to inhaled organic antigens.

The clinical picture shown by these cases was similar to that seen with other causes of extrinsic allergic alveolitis. It should be stressed, however, that the chest radiograph may be normal throughout even though there are clearly defined clinical signs and objective changes in ventilatory function. This may be seen, for example, in case II whose ventilatory function test values are shown in Table XI. As the majority of the regular workers were Indians, the possibility of any specific racial susceptibility being present would be largely obscured.
The technical difficulties in Trinidad of measuring the transfer factor unfortunately precluded its use as a field investigation. The ventilatory function tests showed a restriction in the forced vital capacity with an absence of airways obstruction.

Dust suppression is important, and this has been effectively applied to the control of the disease in the past (Hunter and Perry, 1946). Efforts to minimize airborne dust may include the introduction of exhaust ventilation, the use of a wet process instead of a dry one when this is technically practicable, the enclosure of the machinery, or a combination of such methods. Nevertheless, it can be seen that the suppression of dust has limitations in its value as sporadic cases were still being encountered in the presence of negligible dust concentrations. Masks are probably of some value, although it is difficult to secure an effective mask which will prevent the inhalation of spores without at the same time causing interference with breathing. There is the further problem, in the tropics, of securing the co-operation of employees who are reluctant to be encumbered with a face mask in a hot and humid environment.

The problem of the avoidance of further exposure merits brief consideration. This may present difficulties in the case of the self-employed patient or if alternative employment is not availalbe. In such circumstances, as re-exposure does not inevitably lead to a recurrence of symptoms, a patient may reasonably be allowed to resume his usual occupation after recovery from a single episode. If he should then develop a recurrence, the disease would have to be regarded as potentially disabling in his case, and it would become important to ensure that further re-exposure was avoided as far as possible.

The majority of patients with bagassosis recover spontaneously within four to 12 weeks. It seems probable that, with repeated and reasonably heavy exposure to contaminated bagasse, diffuse pulmonary fibrosis could develop as with farmer's lung. In the cases studied, and with the facilities for pulmonary function testing which were available, it was not possible to demonstrate any residual disability although it would be unlikely that permanent disability would arise from a single episode. The statistically significantly lower ventilatory capacity shown by the group of Indian workers is, however, of concern. In this context it is of interest to note that the two cases of pulmonary fibrosis described by Hunter and Perry and attributed by them to bagassosis were, in fact, less exposed than those who developed the acute syndrome (Hunter and Perry, 1946). Those exposed to higher concentrations of dust would 
tend to have a greater liability to develop the more acute form, and by virtue of so doing would avoid further continued exposure.

Acknowledgements are due to the Board of Directors of Tate and Lyle Limited for permission to publish this paper, and in particular to Mr. J. A. C. Hughill, Director of Tate and Lyle Limited, who was Managing Director of Caroni Limited, Trinidad at the start of this study, for his unfailing personal encouragement and support.

It is a pleasure to record my thanks to Mr. G. Milner, who was General Manager (Operations), Caroni Limited, in the early stages of this work and who gave me his invaluable help from its inception.

I should like to express my especial indebtedness to Professor R. S. F. Schilling, Department of Occupational Health and Applied Physiology, London School of Hygiene and Tropical Medicine for his encouragement, support, and advice in the preparation of this work and for his kindness in arranging for me to obtain the helpful criticisms of members of his Department. In this respect I must especially thank Dr. M. L. Thomson for his advice regarding the pulmonary function testing, Dr. S. A. Roach for his help in relation to the dust measurements, and Miss J. Walford for her advice on the statistical approach, and for the analysis of the data by pooled regression. This material formed part of a thesis approved by the University of London for the degree of M.D.

\section{REFERENCES}

Banerjee, S., and Sen, R. (1955). Determination of the surface area of the body of Indians. f. appl. Physiol., $7,585-588$.

Bayonet, N., and Lavergne, R. (1960). Respiratory disease of bagasse workers-a clinical analysis of 69 Cases. Industr. Med. Surg., 28, 519-522.

Buechner, H. A., Aucoin, E., Vignes, A. J., and Weill, H. (1964). The resurgence of bagassosis in Louisiana. F. occup. Med., 6, 437-442.

—, Prevatt, A., Thompson, J., and Blitz, O. (1958). Bagassosis-a review, with further historical data, studies of pulmonary function and results of adrenal steroid therapy. Amer. F. Med., 25, 234-247.

Campbell, E. J. M., and Howell, J. B. L. (1960). Simple rapid methods of estimating arterial and mixed venous $\mathrm{PCO}_{2}$. Brit. med. F., I, 458-462.

— and, - (1962). Rebreathing method for measurement of mixed venous $\mathrm{PcO}_{2}$. Ibid., 2, 630-633.

Cangini, G. (1951). Casi di bagassosi in Italia. Lotta c. tuberc., 2r, 300 .

Castleden, L. I. M., and Hamilton-Paterson, J. L. (1942). Bagassosis-an industrial lung disease. Ibid., 2, 478-480.

Cotes, J. (1965). Lung Function, Assessment and Application in Medicine, p. 325. Blackwell, Oxford.

- and Malhotra, M. S. (1965). Differences in lung function between Indians and Europeans. F. Physiol. (Lond.), 177, 17-18.

Dizon, G. D., Almonte, J. B., and Anselmo, J. E. (1962). Bagassosis and silicosis in the Philippines. F. Philipp. med. Ass., 38, 865-872.
Fletcher, C. M. (1959). Terminology, definitions, and classification of chronic pulmonary emphysema and related conditions; Ciba Guest Symposium Report, 1958. Thorax, 14, 286-299.

Ganguly, S. K., and Pal, S. C. (1955). Early bagassosis. f. Ind. med. Ass., 24, 253-254.

Gilson, J. C., Stott, H., Hopwood, B. E. C., Roach, S. A. McKerrow, C. B., and Schilling, R. S. F. (1962). Byssinosis: the acute effect on ventilatory capacity of dusts in cotton ginneries, cotton, sisal, and jute mills. Brit. F. industr. Med., 19, 9-18.

Glass, W. I. (1962). Ventilatory function differences between Polynesian and European rope workers. N.Z. med. F. Sci., 6r, 433-444.

Gogate, M. G., Gaula, V. G., and Patil, S. R. (196I). Breathing reserve and breathing capacity in healthy Indian young adult males. F. Ind. med. Ass., 37, 486-488.

Hargreave, F. E., Pepys, J., and Holford-Strevens, V. (1968). Bagassosis. Lancet, $\mathrm{x}, 619-620$.

Hearn, C. E. D., and Holford-Strevens, V. (1968). Immunological aspects of bagassosis. Brit. F. industr. Med., $25,283$.

Hunter, D., and Perry, K. M. A. (1946). Bronchiolitis resulting from the handling of bagasse. Ibid., 3, 64-74.

Jamison, C. S., Bryan, M. S., and Day, J. M. (1944). Bagassosis-a case report. New Orleans med. Surg., 96, $291-294$.

—, and Hopkins, J. (194I). Bagasscosis-a fungus disease of the lung. Ibid., 93, 580-582.

Khandare, S. S., and Sen, S. C. (1962). Pulmonary function tests in healthy young Indian males. Indian f. med. Sci., 16, 338-342.

LeMone, D. V., Scott, W. G., Moore, S., and Koven, A. L. (1947). Bagasse disease of the lungs. Radiology, 49, 556-567.

McDaniel, S., and Hull, J. G. (1952). Bagasse disease of the lungs. Brief review of the literature and report of two cases. Tex. St. F. Med., 48, 820-823.

Medical Research Council. (1960a). Questionnaire on respiratory symptoms.

- (1960b). Instructions for the use of the Questionnaire on respiratory symptoms.

Paul, R., Fletcher, G. H., and Addison, G. (1960). A comparative study between Europeans and Africans in the mining industry of Northern Rhodesia. Med. Proc., 6, 69-74.

Roach, S. A., and Schilling, R. S. F. (1960). A clinical and environmental study of byssinosis in the Lancashire cotton industry. Brit. F. industr. Med., 17, 1-9.

Singh, H. D., and Prabhakaran, S. (1957). Pulmonary function studies. F. Indian med. Ass., 29, 269-272.

Singh, J. N. (1955). Bagassosis. Ibid., 25, 304.

Smetana, H. F., Tandon, H. G., Viswanathan, R., Venkitasubramanian, T. A., Chandrasekhar, S., and Randhawa, H. S. (1962). Experimental bagasse disease of the lung. Lab. Invest., 11, 868-884.

Sodeman, W. A. (1949). Bagasse disease of the lungs. Dis. Chest, 15, 162-166.

- , and Pullen, R. L. (1943). Bagasse disease of the lung. New Orleans med. Surg. F., 95, 558-560.

- , and - (1944). Bagasse disease of the lungs. Arch. intern. Med., 73, 365-374.

Todd, G. F. (1966). Statistics of Smoking in the United Kingdom. (4th ed.). Tobacco Manufacturers' Standing Committee. Research Papers, No. I. London. 
Walford, J., Lammers, B., Schilling, R. S. F., Genderen, D., Weill, H., Buechner, H. A., Gonzalez, E., Herbert, S. J., van den Hoven, van, and Veen, Y. G. van der. (1966). Diurnal variation in ventilatory capacity. An epidemiological study of cotton and other factory workers employed on shift work. Brit. F. industr. Med., 23, 142-148.

\author{
Aucoin, E., and Ziskind, M. M. (1966). Bagassosis: \\ A study of pulmonary function in 20 cases. Ann. \\ intern. Med., 64, 737-747.
}

Wright, B. M. (1954). A size-selecting sampler for airborne dust. Brit. F. industr. Med., 11, 284-288. 